\title{
The problem of paediatric patients in developing countries: do we actually know how to feed the malnourished children?
}

\section{Daniel Kasprowicz ${ }^{\circ}$, Franco Cyrille Rajaomalala}

\author{
Medical Clinic Flamboyant, Mampikony, Madagascar
}

\begin{abstract}
The problem of malnutrition affects both developed and developing countries. The disease-related malnutrition in hospitalised patients is well-described and the treatment recommendations reflect the health care conditions of developed countries. However the diagnosis and treatment of children with severe acute malnutrition (SAM) is inconsistent both in the international and in the developing countries' guidelines. The aim of this article is to start a discussion about the guidelines for the treatment and nutrition of malnourished infants and children in developing countries. The differences appear primarily in the hydration and nutritional status assessment, treatment of hypoglycaemia, additional supplementation and partly in nutrition itself. In general, we do know how to treat children with SAM, however the differences in the guidelines can cause a lot of difficulty in making decisions in emergencies, particularly for infants under 6 months.
\end{abstract}

Keywords: severe acute malnutrition $\cdot$ infants $\cdot$ supplementation $\cdot$ nutritional status assessment $\cdot$ WHO protocol

\section{Citation}

Kasprowicz D, Rajaomalala FC, The problem of paediatric patients in developing countries: do we actually know how to feed the malnourished children? Eur J Transl Clin Med. 2019;2(2):7-18.

DOI: $10.31373 / \mathrm{ejtcm} / 116313$

\section{Introduction}

The problem of world hunger is not new, however the recent trends in global food security force us to ask questions about the effectiveness of international interventions. Although the newest United Nations Food and Agriculture Organisation (FAO) statistics show a clear distribution of malnourished people in different regions of the world, the data also indicate that we are not winning the battle with famine. Furthermore, sin- ce 2014 the fight against hunger seems to be moving towards global failure with a large increase in people suffering from overweight and obesity [1]. In developed countries malnutrition is related with chronic or acute disease and most often affects hospitalised patients ( 20 to $50 \%$ of patients, depending on the hospital department or the nature) [2-3]. Therefore, hunger result-ing from food insecurity is rather the domain of 
developing countries, mainly countries in sub-Saharan Africa, Central Asia and Southern Asia. Statistically, $25.9 \%$ of the African population does not have adequ ate access to nutritious food and $30.3 \%$ of children $<5$ years of age are malnourished [1]. Moreover, statistics do not include micronutrient-related malnutrition and micronutrient excess, which may suggest that malnourishment is a bigger problem quantitatively [4]. The quick progress of knowledge in nutritional sciences, development of nutritional status assessment methods and nutritional risk, accessibility of artificial diets and nutritional teams enabled effective treatment of disease-related malnutrition [5-13].

However, using the developed countries' standards to treat and feed malnourished patients in developing countries is impossible due to the insufficient quantity of ready-to-use therapeutic food (RUTF) and oral nutritional supplements (ONS), lack of medical and technological resources, low financial support and inadequate training of health workers. Although the World Health Organisation (WHO), UNICEF or Doctors without borders (Médecins sans frontières, MSF) published several guidelines and assessment tools, many of the presented algorithms for the treatment of malnutrition are still not implemented [14-16]. Among the reasons for this situation is the complex task of adapting the guidelines to the local resources and capabilities, the co-occurence of malnutrition and tropical diseases and the relatively scarce evidence base for the treatment of malnutrition of infants $<6$ months of age [17-18]. In addition, many of the countries struggling to provide effective care for the malnourished paediatric patients also lack funding for research, hence the specific and critical research questions regarding the nutrition or nursing care (which are not yet addressed by the aforementioned guidelines) remain unanswered and the evidence base remains scarce.

The aim of the article is to start a discussion about the treatment and nutrition of malnourished infants and children in developing countries. In addition, it is important to note the lack of specific nutrition standards and lack of consistent international guidelines, especially among children $<6$ months of age. The authors would like to emphasize that this article is not intended to suggest standards for the treatment of malnourished children in developing countries.

\section{Nutritional Status Assessment}

Accurate nutritional status assessment (NSA) is the first and key element in the diagnosis of severe acute malnutrition (SAM) in paediatric patients [19]. SAM consists of two basic forms: severe wasting (also described as marasmus or energy malnutrition) and nutritional oedema (also described as kwashiorkor or protein malnutrition). Marasmus is a consequence of uncomplicated prolonged starvation. It is mainly characterised by a decrease in body weight and other anthropometric and immunological indicators. Usually, total protein and serum albumin are normal or slightly below normal. There is also a shortage of minerals and vitamins such as iron, iodine, zinc and vitamin A. Kwashiorkor is a result of hypercatabolism due to qualitative and quantitative malnutrition. Patients have a decrease in protein fractions in the blood serum, which results in oedema and apparent weight gain [1, 14-15, 20-21]. Both types of malnutrition can also be caused by bacterial, viral and parasitic infections or by the combined burden of malnutrition and tropical diseases [22]. WHO also distinguishes a third type: marasmic kwashiorkor characterised by a decrease in muscle mass and fat, sarcopenia, weakening of the im-mune system, anaemia, lowering of protein levels in blood serum, digestive and absorption disorders as well as impairment of organs and body systems [15, 20-21].

Criteria for pharmacological and nutritional treatment of SAM

Although the scientific societies established several criteria for diagnosing malnutrition, none are spe-cific to children $<6$ months. Using different methods of NSA in the same group of patients, we can obtain significant differences in the percentage distribution of well-fed and malnourished patients [2]. This poses the risk of not diagnosing early malnutrition, which may manifest with symptoms or biological changes not included in the basic parameters of the selected NSA method [15]. A special treatment algorithm is intended for children with SAM. Some recommendations suggest using selected algorithms also to treat children with moderate acute malnutrition (MAM), but NSA determined by different methods can lead to the exclusion of some paediatric patients [14-17].

The most popular and oldest method of NSA among paediatric patients is to determine abnormalities in weight and height/length on percentile charts regarding weight-for-height/length, however since 2005 the WHO recommends that mid-upper arm circumference (MUAC) and the occurrence of oedema as independent diagnostic indicators of malnourishment [2, 23-24]. The index of weight-for-height/length primarily gives information about weight loss compared to children with good nutritional status of the same height/length. MUAC indicates loss of muscle mass and gives quick 
check of infants and children's nutritional status [14] Comparing these two measurements, MUAC seems to play a more important role because it is a more reliable parameter, burdened with less risk of incorrect measurement, and can also be used by minimally-trained non-professionals for community-based screening of SAM in infancy [25]. WHO, UNICEF and MSF unanimously propose that in developing countries for the diagnosis of SAM and thus for pharmacological and nutritional treatment, children should meet the criteria:

- the MUAC in infants and children 6-59 months is $<115 \mathrm{~mm}$,

- and/or bilateral pitting oedema,

- and/or a weight-for-height/length $<3$ Z-score

of the WHO growth standards

Some recommendations suggest MUAC $<110 \mathrm{~mm}$, but using this criteria may lead to under-diagnosis. Besides proper anthropometric parameters attention should be paid to other elements that may be the first symptoms of micronutrient-related malnutrition and micronutrient excess. During the history-taking, it is worth asking about the current diet and breastfeeding time, birth weight, vaccinations, episodes of diarrhoea and vomiting, urine colour, and contact with people suffering from infectious diseases. In physical examination, it is important to check the basic life parameters, size of the liver and spleen, peristalsis sounds on auscultation, skin pallor, signs of circulatory collapse and any changes in the eyes, ears, skin and hair [14-17, 25-26]. The circumference of the child's head is not recommended because of statistically significant variation within nations and ethnic groups, leading to overdiagnosis of macrocephaly or microcephaly may occur. Also, growth percentiles charts may not be optimal in all cases and a very careful and individual examination is required [27].

\section{SAM in infants under 6 months of age}

For many years, the issue of diagnosing and treating malnourished infants under 6 months of age was underestimated, and in international and national guidelines little or no attention was paid to it. Furthermore, each guideline points to completely different factors causing malnutrition as well as factors affecting the treatment process. Using the guidelines to make the decision to hospitalise an infant patient is also difficult. The criteria that are strongly recommended for defining SAM and MAM in infancy and for starting a nutritional intervention are:

- weight-for height/length $<3$ Z-score of the WHO growth standards,
- and/or the presence of bilateral oedema.

Other parameters which are worth attention:

- infant is too weak to be breastfed,

- and/or insufficient milk production by the mother,

- and/or body length below $49 \mathrm{~cm}$,

- and/or the infant has not gained any weight within 1-2 weeks,

- and/or weight loss has been observed.

So far no recommendation was made to divide SAM into complicated and uncomplicated forms [17]. Some recommendations suggest that patients $<3 \mathrm{~kg}$ $[17,28-36]$ or $<4 \mathrm{~kg}$ [37-38] should be treated and fed as patients under 6 months. None of the guidelines focus on NSA of infants $<6$ months. Studies show that scales used in nutrition-related emergencies are largely unsuitable for weighing infants $<6$ months [39]. International and national guidelines also does not recommend MUAC for NSA of infants under 6 months [17], but independent medical institutions pointed to MUAC as a simple and easy method for quickly diagnosing infants with MAM and SAM [25].

Nutritional and pharmacological treatment

The comprehensive treatment of a malnourished child consists of three phases: initial treatment (also referred to as stabilisation phase; up to 7 days), rehabilitation (2-6 weeks) and continuation of treatment including emotional stimulation and sensory development of the child. In terms of nutrition, the first phase is the most important and contains many tasks that must be undertaken by a physician, a dietitian or a nurse, e.g. treatment (or prevention) of hypoglycaemia, hypothermia and dehydration, water and electrolyte imbalance, treatment of possible infections, careful start of nutrition as well as diagnosis and treatment of comorbidities (e.g. vitamin deficiency, heart failure or anaemia) (Figure 1) [17, 26, 40].

\section{Hypoglycaemia}

Hypoglycaemia in children with SAM is diagnosed when blood glucose level is $<54 \mathrm{mg} / \mathrm{dL}(<3 \mathrm{mmol} / \mathrm{L})$, but MSF suggests intervening in blood glucose $<60$ $\mathrm{mg} / \mathrm{dL}$ ( $<3.3 \mathrm{mmol} / \mathrm{L}$ ) [26]. Severe hypoglycaemia is a condition when the blood glucose level is $<40 \mathrm{mg} /$ $\mathrm{dL}(<2.2 \mathrm{mmol} / \mathrm{L})$ [14]. The most common causes of hypoglycaemia in children with SAM or MAM are: 


\section{Stabilisation}

phase

\section{Hypoglycaemia}

2. Hypothermia

3. Dehydration

\section{Electrolytes}

\section{Infections}

\section{Mictronutrients}

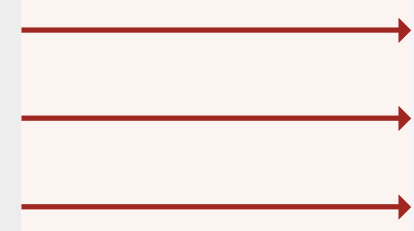

\section{Cautious feeding}

\section{Catch-up growth}

\section{Sensory stimulation}

\section{Prepare for follow-up}

- a reduced amount of stored glucose in the muscles (decrease in muscle mass, wasting),

- weakening of glucose conversion mechanisms (due to increased metabolism of proteins and fats),

- immune response to infection (including the particularly dangerous Plasmodium falciparum infection),

- impaired glucose absorption in the gastrointestinal tract (atrophy of the intestinal villi, gastrointestinal mycosis),

- prolonged fasting and delayed introduction of nutrition (due to the long journey to the hospital) [26, 41-43].
If hypoglycaemia occurs in a child with SAM, immediate intervention should take place because this is the main cause of death in the first phase of treatment. If it is not possible to check the blood glucose level, it is recommended to administer prophylactic glucose solutions based on clinical symptoms [26]. Treatment of hypoglycaemia in the most common conditions is presented in Table $1[14,16-17,26]$.

Table 1. Management of hypoglycaemia in various states

\begin{tabular}{|c|c|c|}
\hline Statement & Intervention & Comments \\
\hline $\begin{array}{l}\text { Unconscious } \\
\text { / convulsive child }\end{array}$ & $\begin{array}{c}5 \mathrm{ml} \text { of } 10 \% \text { sterile glucose } \\
\text { i.v./kg body weight } \\
(2-3 \text { minutes })\end{array}$ & $\begin{array}{l}\text { 1. Check the glucose level after } 15 \\
\text { minutes. If blood glucose level is still } \\
\text { below the norm, give an another bolus. } \\
\text { 2. After regaining consciousness, feed } \\
\text { with } \mathrm{F}-75^{\mathrm{A}} \text { diet. } \\
\text { 3. If there is no improvement, rapid } \\
\text { diagnosis for another factors causing } \\
\text { hypoglycaemia * }\end{array}$ \\
\hline
\end{tabular}




\begin{tabular}{|c|c|c|}
\hline $\begin{array}{l}\text { Unconscious child } \\
\text { with a nasogastric } \\
\text { tube (NG) }\end{array}$ & $\begin{array}{c}5 \mathrm{ml} 10 \% \text { sterile glucose } \\
\text { per kg body weight i.v. } \\
\text { ( } 2-3 \text { minutes) and then } 50 \mathrm{ml} \\
\text { of } 10 \% \text { solution of glucose } \\
\text { or sucrose by NT }\end{array}$ & $\begin{array}{l}\text { 1. If vascular access is not available, } \\
50 \mathrm{ml} \text { of a } 10 \% \text { glucose or glucose } \\
\text { solution should be first administered } \\
\text { via the NG } \\
\text { 2. After regaining consciousness, feed } \\
\text { with } \mathrm{F}-75 \text { diet or glucose dissolved } \\
\text { in water ( } 60 \mathrm{~g} / \mathrm{L} \text { ) } \\
\text { 3. If there is no improvement, rapid } \\
\text { diagnosis for another factor causing } \\
\text { hypoglycaemia * }\end{array}$ \\
\hline $\begin{array}{l}\text { Conscious child, } \\
\text { without NG }\end{array}$ & $\begin{array}{l}50 \mathrm{ml} \text { of } 10 \% \text { glucose or sugar } \\
\text { solution orally, next start F-75 } \\
\text { diet every } 30 \text { minutes for the } \\
\text { next } 2 \text { hours. Then give a meal } \\
\text { rich in complex carbohydrates. }\end{array}$ & $\begin{array}{l}\text { 1. If there is no improvement, rapid } \\
\text { diagnosis for another factor causing } \\
\text { hypoglycaemia * }\end{array}$ \\
\hline Infant $<6$ months & Diluted $\mathrm{F}-100^{\mathrm{B}} * *$ & No information provided \\
\hline
\end{tabular}

* No clinical improvement may suggest severe infection (e.g. malaria, meningitis) or epilepsy. Perform a quick diagnostic test and then apply the appropriate treatment (antibiotic therapy, anti-malarial therapy, anti-epileptic therapy) with the symptomatic treatment of hypoglycaemia.

** MSF 2006 recommendation for the prevention of hypoglycaemia in children with SAM. However the WHO, MSF and UNICEF guidelines do not include specific recommendations for the treatment of hypoglycaemia in infants $<6$ months of age.

A Formula 75; therapeutic milk, $100 \mathrm{ml}$ of F-75 provides $75 \mathrm{kcal}$ and $1 \mathrm{~g}$ of protein

B Formula 100; therapeutic milk, $100 \mathrm{ml}$ of F-100 provides $100 \mathrm{kcal}$ and $3 \mathrm{~g}$ of protein

There are infections that can significantly lower blood glucose levels, and thus reduce the effectiveness of conservative treatment. In the case of malaria (P. falciparum) infection, there is a decrease in blood glucose as a result of multi-enzymatic changes caused by infection and simultaneous starvation on the one hand [44-45], and on the other hand the treatment with quinine or quinidine leads to hyper-insulinemic hypoglycaemia [46-47]. It is recommended to administer either drug by constant infusion with $5 \%$ glucose, active feeding during the disease and regular glucose measurement [14].

\section{Hydration status assessment}

Hydration status assessment (HSA) of malnourished paediatric patients is very difficult due to the differences in the dehydration symptoms in different types of malnutrition. Furthermore, it is often difficult to determine the acute symptoms of dehydration and chronic symptoms of malnutrition. Dehydration is a serious he- alth problem in the first phase of treatment and just like hypoglycaemia, it is one of the main causes of death in the course of MAM or SAM. The most severe complication is severe hypovolemic shock $[14,17]$. MSF and WHO suggest dividing patients into three groups: no signs of dehydration, moderate dehydration, and severe dehydration. More specific differences and assessment of dehydration severity are included in Table $2[16,48]$. Matiland et al asked a bold question whether the risk of death in children with SAM could be identified using WHO protocols. In children with diarrhoea, hydration status was of limited importance as a prognostic symptom because only $58 \%$ of deceased children were assessed as moderately or severely dehydrated. CRT best identified the high risk of death [49]. In properly hydrated patients, oral rehydration salts (ORS) are used to prevent dehydration. In children $<2$ years of age it is recommended to administer $50-100 \mathrm{ml}$ after each stool until diarrhoea disappears. In moderately or severely dehydrated patient without hypovolemic or septic shock, it is recommended to give ORS 5-10 ml/ $\mathrm{kg} / \mathrm{h}$ for up to 12 hours orally. In case of swallowing 
Table 2. Hydration status assessment

\begin{tabular}{|c|c|c|c|}
\hline Parameter & Normal & Moderate dehydration & Severe dehydration \\
\hline Awareness & Normal & Confused & Sleepy or unconscious \\
\hline $\begin{array}{l}\text { Subcutaneous } \\
\text { tissue }\end{array}$ & Tense & Sunken around the eyes & $\begin{array}{l}\text { Sunken around the eyes, } \\
\text { sunken fontanelle }\end{array}$ \\
\hline $\begin{array}{l}\text { Capillary } \\
\text { Refill Time }\end{array}$ & Normal & $<2 \mathrm{sec}$ & $>2 \mathrm{sec}$ \\
\hline Thirst & Normal & Intensified & Intensified or none \\
\hline Heart Rate & Normal & Tachycardia & $\begin{array}{l}\text { Tachycardia, cooling } \\
\text { of the peripheral parts }\end{array}$ \\
\hline Pulse & Easily palpable & Palpable & Difficult to palpate \\
\hline Weight Loss & $<1 \%$ & $1-5 \%$ & $5-10 \%$ \\
\hline Other & $\begin{array}{l}\text { Person drinks } \\
\text { normally }\end{array}$ & History of watery stools & $\begin{array}{l}\text { (1) Hypotension, } \\
\text { (2) Loss of tears, dry tongue, } \\
\text { reduced diuresis, } \\
\text { (3) watery diarrhoea ( }>3 x \\
\text { loose, watery stools/day) } \\
\text { is a specific parameter }\end{array}$ \\
\hline
\end{tabular}

difficulty, fluids administration via nasogastric tube is recommended. For patients with complications, it is worth using the algorithm proposed by MSF suggesting the intravenous administration of a sterile solution of Ringer Lactate-Glucose 5\% (RL-G\%) [16]. Hydration is based on the daily hydration requirement (DHR) presented in Table 3 [16]. In the case of significant weight loss due to dehydration, it is recommended to multiply the DHR by 1,5 . If RL-G5\% is unavailable, it is recommended to prepare your own formula by adding a steri- le $50 \%$ glucose solution to $500 \mathrm{ml} \mathrm{RL}$. If $\mathrm{RL}$ is unavailable, $0.9 \%$ saline may be used $[16-17,26]$. Many national and international guidelines are based on the WHO recommendations from 1999 and still suggest to treat severe dehydration with intravenous half-strength Darrow's solution with $5 \%$ glucose (dextrose) as the first choice and $0.45 \%$ (half-normal) saline with $5 \%$ glucose with $20 \mathrm{mmol} / \mathrm{L}$ potassium chloride $[14,17]$. In contrast, the more recent WHO guidelines from 2013 recognised the aforementioned recommendations as a conditional

Table 3. Daily hydration requirements

\begin{tabular}{|c|c|}
\hline Weight [kg] & Dosage \\
\hline $0-10$ & $100 \mathrm{ml} / \mathrm{kg}$ per day \\
\hline $11-20$ & $1000 \mathrm{ml}+(50 \mathrm{ml} / \mathrm{kg}$ for every $\mathrm{kg}$ over $10 \mathrm{~kg})$ per day \\
\hline$>20$ & $1500 \mathrm{ml}+(20-25 \mathrm{ml} / \mathrm{kg}$ for every $\mathrm{kg}$ over $20 \mathrm{~kg})$ per day \\
\hline
\end{tabular}

Source of data: MSF guidelines [16] 
choice, and that the evidence for the effectiveness of such treatment is of very low quality. This was due to the limited availability of randomised controlled trials, trials comparing existing WHO recommendations with new treatment options, or trials documenting comparisons of diagnoses and treatment methods [26].

There are no specific guidelines for HSA in children $<6$ months. Nevertheless, the MAMI report indicates that the WHO, UNICEF and MSF guidelines can also be used in newborns [17]. It is important to monitor progress during hydration (pulse rate, respiratory rate, urine frequency, stool/vomit frequency) every half hour for the first 2 hours and then every hour for 6-12 hours. In addition, the appearance of tears, moisture in the mouth, shortening of CRT, reduction of the collapse of the fontanelle and eyes may indicate a positive hydration process. However, attention should be paid to chronically malnourished patients, because even after adequate hydration these features may remain unchanged. There is a huge risk of over-hydration, which can also be fatal [50]. The 2006 MSF Nutrition Protocol highlights fluid therapy for watery diarrhoea. In diarrhoea without dehydration and without above-mentioned features, ORS are not advised and frequent oral hydration with water is recommended, not ORS. In the case of aversion to drinking plain water, the guidelines recommend oral administration of $50 \mathrm{ml}$ of a $10 \%$ sugar solution after each loose stool and HSA every 4 hours, mainly controlling weight loss. The goal of this procedure is to avoid complications associated with hydration, mainly over-treatment with fluids [48].

An important element in the treatment of dehydration associated with severe diarrhoea is additional zinc supplementation. In international and national guidelines, supplementation with this element was limited to the use of rehydration solution for malnutrition (ReSoMal), which contains $0.3 \mathrm{mmol}$ of zinc per litre of solution [16-17]. MSF Nutrition recommends supplementation with $10 \mathrm{mg}$ zinc for 10 days in children < 6 months, and $20 \mathrm{mg}$ zinc for 10 days in children $>6$ months [48]. Many randomised studies have demonstrated the effectiveness of additional zinc supplementation in children $>6$ months of age, but the significance in children < 6 has been questioned [51-53].

\section{Additional supplementation}

Serum levels of vitamin A, folic acid (FA) and iron should be laboratory checked in malnourished child- ren, even if there are no clinical signs of deficiency [48]. Despite the recommendations to monitor these three micronutrients, especially in children with SAM > 6 months [17], the lack of access to medical laboratories, qualified laboratory personnel and medical equipment creates a significant barrier in Sub-Saharan Africa [54]. Thus, in many cases the deficiencies of these components are determined when significant clinical symptoms already occur and often are very difficult to treat with inexpensive medicaments or when the patient is acutely ill. This is the a paradox of the requirements imposed by the guidelines of global organisations that cannot realistically be met in underfunded and underequipped health care facilities in developing countries.

\section{Vitamin A}

Supplementation with vitamin A, and its derivatives are used to prevent xerophthalmia and blindness, and to treat malnutrition and intestinal diseases. The incidence of infectious diseases decrease, and indirectly the mobility reduction, could be obtained through vitamin A related to gut immune tolerance/homeostasis, intestinal barrier integrity, and responses to enteropathogens in the context of the environmental enteric dysfunction [55-60]. The MSF Nutrition Protocol recommends a single dose of 100,000 IU for children 6-12 months and 200,000 IU for children > 1 year [48]. 8 of 14 international guidelines and 15 of 23 national guidelines $^{1}$ suggest supplementation of 50,000 IU vitamin A once orally on the first day of admission in children < 6 months [17]. A 2003 WHO report states that supplementing 5,000 IU of vitamin A daily during the hospital stay yields much better results than a single dose of 100,000 IU. This method of supplementation prevents severe diarrhoea and respiratory diseases. A single dose seems to bring good results only during measles, in ongoing infectious diarrhoea and clinical symptoms of deficiency of this vitamin [26].

\section{Haematopoietic elements}

Vitamin $\mathrm{B}_{12}$, $\mathrm{FA}$ and iron ( $\mathrm{Fe}$ ) supplementation are considered for the prevention and treatment of anaemia. The WHO, MSF and UNICEF recommend a single dose of $5 \mathrm{mg}$ FA orally on the day of admission. Iron supplementation is recommended only during the rehabilitation phase due to iron toxicity, which in

\footnotetext{
${ }^{1}$ Guidelines from countries in sub-Saharan Africa, Central Asia and Southern Asia.
} 
malnourished patients may increase oxidative stress, contribute to electrolyte imbalance, disrupt metabolic processes and worsen intestinal infections. Only after correction of critical abnormalities (about 2 weeks), it is recommended to supplement $\mathrm{Fe}$ in children $>6$ months ( $3 \mathrm{mg}$ of elemental $\mathrm{Fe} / \mathrm{kg}$ in 2 divided doses) [48]. Only 2 of 14 international guidelines and 2 of 23 national guidelines recommended similar supplementation in children $<6$ months [17]. One national guideline recommended supplementation double dose of elemental iron in malnourished infants. In other guidelines, the recommendation was either not provided or nutritional treatment with the F-100 formula was considered sufficient [17]. Although many studies have shown equal and sometimes significantly greater importance of vitamin $B_{12}$ in preventing and treating anaemia in children with SAM, none of the guidelines recommend its supplementation [61-65].

\section{Cautious feeding}

Depending on the child's age, severity of malnutrition and associated diseases, nutritional treatment involves breastfeeding, formula F-75, formula F-100, diluted formula F-100 (F-100D), infant formula (IF), ready-to-use therapeutic food (RUTF), oral nutritional supplements (ONS), and home-made milk feeds. The first phase of treatment (up to 7 days) is extremely important due to the fact of a precisely calculated dose of food, which aims to avoid failure in the treatment of malnutrition and especially overnutrition, including in the form of re-feeding syndrome. Most guidelines are consistent as to the frequency and methods of feeding in the first phase of treatment. A child $>6$ months of age should be fed orally using a teaspoon, cup or syringe. If the child is unable to swallow food on its own, it is rec-ommended to feed via nasogastric (NG) tube and to withdraw it as soon as the child is able to swallow. The guidelines are consistent as to the gradual feeding of the child with the appropriate calories. Muscle and tissue catabolism will increase when feeding $<80 \mathrm{kcal} /$ $\mathrm{kg} /$ day, while feeding $>100 \mathrm{kcal} / \mathrm{kg} /$ day may contribute to a serious metabolic imbalance. The main complications of overnutrition and overhydration in the first phase of treatment are congestive heart failure and death. Most common errors are due to excessive volume of food given at one time, excessive sodium intake and high protein intake. International and national guidelines have well-described tables, thanks to which health care workers can easily calculate and monitor the amount of food administered [14-17, 26, 39, 48]. The problem begins in children with SAM $<6$ months because many guidelines do not specify this group in their dietary recommendations. In 6 of 13 international guidelines this topic was omitted completely, in 7 of 13 it was recommended to continue breastfeeding without detailed information, and 6 of 13 guidelines recognised F-75, F-100, F-100D and IF as a substitute for breastfeeding and details of feeding were presented [17]. What the guidelines do not seem to take into account is the maternal peridelivery mortality in developing countries, which results in orphaned infants for whom no breastmilk is available due to the lack of breast milk banks.

In a double-blind randomised trial, F-100 and F-100D were found to be of high safety in children $<6$ months. In addition, F-100 restored the nutritional status of children much more effectively and faster than IF [66]. Attempts have also been made to examine the transition from formula F-75 to RUTF according to WHO recommendations. It turned out that the transition in the first time was only possible in $65 \%$ of cases, and almost impossible in acutely malnourished children or those with severe illnesses [67]. Rytter et al showed a strong correlation between feeding milk-rice porridges to children with SAM and the occurrence of refeeding syndrome (even with moderately low plasma phosphate levels) and F-75 was considered a safer product [68].

Nevertheless, there are questions about the availability of these nutritional preparations, both ready-made offered by WHO/UNICEF and those prepared at hospital or home using the recipes provided in the WHO and UNICEF training materials. In both cases, there are often problems with the distribution of food products or individual ingredients to create a standardised nutrient. This is often deepened by social unrest, corruption and a lack of financial support for treatment facilities in developing countries. Furthermore, compared to alternative nutritional approaches, RUTF improves recovery and slightly increases the rate of weight gain. Unfortunately, the effect on malnutrition recurrence or mortality after going on a normal diet is not fully known. The authors recommend further randomised controlled trials [69].

\section{Conclusion}

The lack of consistency between international and national guidelines on nutrition of children with SAM makes it difficult to treat malnourishment in developing countries and most understatements occur in the treatment of infants $<6$ months old. This topic requires many research trials that will significantly help tosolve the problem of diagnosis and pharmacological-nutritional treatment of children 0-59 months. 
It is necessary to unify the NSA and the rules of admitting children for nutritional treatment in medical facilities, because underdiagnosis may end in unnecessary death. In addition, specialised expert groups studying the problem of malnutrition should attempt to present new treatments that could be used in the field internationally. The experience of local medical personnel who care for the malnourished should also be taken into account. It is also worth asking the question why there is the problem of so many differences in treatment protocols, and why there is so little scientific research in places affected by poverty. If almost $1 / 3$ of children under 5 are malnourished in Africa, this fact should motivate to create professional and reliable standards of treatment child with SAM in developing countries.

\section{References}

1. FAO. The state of food security and nutrition in the world 2018. Building climate resilience for food security and nutrition [Internet]. 2018 [cited 2019 Nov 7]. Available from: www.fao.org/publications

2. Kang MC, Kim JH, Ryu S-W, Moon JY, Park JH, Park JK, et al. Prevalence of malnutrition in hospitalized patients: a multicenter cross-sectional study. J Korean Med Sci [Internet]. 2018 [cited 2019 Nov 7];33(2):e10. Available from: https:// www.ncbi.nlm.nih.gov/pmc/articles/PMC5729651/

3. Barker L, Gout B, Crowe T. Hospital malnutrition: prevalence, identification and impact on patients and the healthcare system. Int J Environ Res Public Health [Internet]. 2011 [cited 2019 Nov 8];8(2):514-27. Available from: http://www.ncbi. nlm.nih.gov/pubmed/21556200

4. Hwalla N, Al Dhaheri AS, Radwan H, Alfawaz HA, Fouda MA, Al-Daghri NM, et al. The prevalence of micronutrient deficiencies and inadequacies in the middle east and approaches to interventions. Nutrients [Internet]. 2017 [cited 2019 Nov 8];9(3):229. Available from: http://www.mdpi.com/2072-6643/9/3/229

5. Cederholm T, Barazzoni R, Austin P, Ballmer P, Biolo G, Bischoff SC, et al. ESPEN guidelines on definitions and terminology of clinical nutrition. Clin Nutr [Internet]. 2017 [cited 2019 Nov 8];36(1):49-64. Available from: http://dx.doi. org/10.1016/j.clnu.2016.09.004

6. Cederholm T, Bosaeus I, Barazzoni R, Bauer J, Van Gossum A, Klek S, et al. Diagnostic criteria for malnutrition - an ESPEN Consensus Statement. Clin Nutr [Internet]. 2015 [cited 2019 Nov 8];34(3):335-40. Available from: http://www.ncbi.nIm. nih.gov/pubmed/25799486

7. Arends J, Baracos V, Bertz H, Bozzetti F, Calder PC, Deutz NEP, et al. ESPEN expert group recommendations for action against cancer-related malnutrition. Clin Nutr [Internet]. 2017 [cited 2019 Nov 8];36(5):1187-96. Available from: https:// doi.org/10.1016/i.clnu.2017.06.017

8. Bischoff SC, Austin P, Boeykens K, Chourdakis M, Cuerda C, Jonkers-Schuitema C, et al. ESPEN guideline on home enteral nutrition. Clin Nutr [Internet]. 2019 [cited 2019 Nov 8]; Available from: https://doi.org/10.1016/i.clnu.2019.04.022

9. Koletzko B, Goulet O, Hunt J, Krohn K, Shamir R, Parenteral Nutrition Guidelines Working Group, et al. Guidelines on paediatric parenteral nutrition of the European Society of Paediatric Gastroenterology, Hepatology and Nutrition (ESPGHAN) and the European Society for Clinical Nutrition and Metabolism (ESPEN), supported by the European Society of Paediatri. J Pediatr Gastroenterol Nutr [Internet]. 2005 [cited 2019 Nov 8];41 Suppl 2(Supplement 2):S1-87. Available from: http:// www.sign.ac.

10. Turck D, Braegger CP, Colombo C, Declercq D, Morton A, Pancheva R, et al. ESPEN-ESPGHAN-ECFS guidelines on nutrition care for infants, children, and adults with cystic fibrosis. Clin Nutr [Internet]. 2016 [cited 2019 Nov 8];35(3):557-77. Available from: https://doi.org/10.1016/i.clnu.2016.03.004

11. Druml C, Ballmer PE, Druml W, Oehmichen F, Shenkin A, Singer $P$, et al. ESPEN guideline on ethical aspects of artificial nutrition and hydration. Clin Nutr [Internet]. 2016 [cited 2019 Nov 8];35(3):545-56. Available from: http://dx.doi. org/10.1016/i.clnu.2016.02.006

12. Mihatsch W, Shamir R, van Goudoever JB, Fewtrell M, Lapillonne A, Lohner S, et al. ESPGHAN/ESPEN/ESPR/CSPEN guidelines on pediatric parenteral nutrition: guideline development process for the updated guidelines. Clin Nutr [Internet]. 2018 [cited 2019 Nov 8];37(6):2306-8. Available from: https://doi.org/10.1016/i.clnu.2018.06.943

13. Kondrup J. ESPEN Guidelines for Nutrition Screening 2002. Clin Nutr [Internet]. 2003 [cited 2019 Nov 8];22(4):415-21. Available from: https://linkinghub.elsevier.com/retrieve/pii/S0261561403000980

14. WHO. Management of severe malnutrition: a manual for physicians and other senior health workers [Internet]. [cited 2019 Nov 8]. Available from: https://www.who.int/nutrition/publications/en/manage severe malnutrition eng.pdf 
15. WHO, Unicef. WHO child growth standards and the identification of severe acute malnutrition in infants and children [Internet]. [cited 2019 Nov 8]. Available from: www.who.int/childgrowth/standards

16. MSF. Clinical guidelines - diagnosis and treatment manual [Internet]. 2019th ed. 2019. Available from: https://medicalguidelines.msf.org/msf-books-hosting/14385582-English.pdf

17. Kerac M, Mcgrath M, Grijalva-Eternod C, Bizouerne C, Saxton J, Bailey H, et al. Management of Acute Malnutrition in Infants (MAMI) project. Technical review: current evidence, policies, practices \& programme outcomes [Internet]. 2010 [cited 2019 Nov 19]. Available from: https://reliefweb.int/sites/reliefweb.int/files/resources/8A7E77D26B35660F492576F70010D7DF-mami-report-complete.pdf

18. The double burden of malnutrition. Case studies from six developing countries [Internet]. 2006 [cited 2019 Nov 8]. Available from: http://www.fao.org/3/a0442e/a0442e00.pdf

19. Green Corkins K, Teague EE. Pediatric nutrition assessment. Nutr Clin Pract [Internet]. 2017 [cited 2019 Nov 8];32(1):4051. Available from: http://doi.wiley.com/10.1177/0884533616679639

20. Müller O, Krawinkel M. Malnutrition and health in developing countries. CMAJ [Internet]. 2005 [cited 2019 Nov 8];173(3):279-86. Available from: http://www.cmaj.ca/cgi/doi/10.1503/cmaj.050342

21. Velly H, Britton RA, Preidis GA. Mechanisms of cross-talk between the diet, the intestinal microbiome, and the undernourished host. Gut Microbes [Internet]. 2017 [cited 2019 Nov 8];8(2):98-112. Available from: https://www.tandfonline. com/doi/full/10.1080/19490976.2016.1267888

22. Farhadi S, Ovchinnikov R. The relationship between nutrition and infectious diseases: a review. Biomed Biotechnol Res J [Internet]. 2018 [cited 2019 Nov 8];2(3):168. Available from: http://www.bmbtri.org/text.asp?2018/2/3/168/240706

23. Fernandez MAL, Delchevalerie $P$, van Herp M. Accuracy of MUAC in the detection of severe wasting with the new WHO growth standards. Pediatrics [Internet]. 2010 [cited 2019 Nov 8];126(1):e195-201. Available from: http://pediatrics.aappublications.org/cgi/doi/10.1542/peds.2009-2175

24. Jacob A, Iboyi K, Zha L. Severe Acute Malnutrition (SAM) evaluation of associated risk factors, screening tools, and therapeutic management among South Sudanese children age $6<59$ months in emergency settings: case reports and review of literatures. J Trop Dis. 2019;7(2):298.

25. Mwangome MK, Fegan G, Mbunya R, Prentice AM, Berkley JA. Reliability and accuracy of anthropometry performed by community health workers among infants under 6 months in rural Kenya. Trop Med Int Heal [Internet]. 2012 May [cited 2019 Nov 8];17(5):622-9. Available from: https://reliefweb.int/sites/reliefweb.int/files/resources/8A7E77D26B35660F492576F70010D7DF-mami-report-complete.pdf

26. WHO. Guideline: updates on the management of severe acute malnutrition in infants and children [Internet]. Geneva; 2013 [cited 2019 Nov 8]. Available from: www.who.int

27. Natale V, Rajagopalan A. Worldwide variation in human growth and the World Health Organization growth standards: a systematic review. BMJ Open [Internet]. 2014 [cited 2019 Nov 8];4(1):e003735. Available from: http://www.ncbi.nlm. nih.gov/pubmed/24401723

28. MSF. Nutrition guidelines [Internet]. 1995 [cited 2019 Nov 8]. Available from: https://www.unhcr.org/3c4d391a4.pdf

29. Politique nationale de nutrition [Internet]. [cited 2019 Nov 8]. Available from: http://extwprlegs1.fao.org/docs/pdf/ $\underline{\text { mli152514.pdf }}$

30. Nutrition Unit of the Ministry of Health. Malawi guidelines for community-based management of acute malnutrition, 2nd edition [Internet]. 2016 [cited 2019 Nov 8]. Available from: https://www.fantaproject.org/sites/default/files/resources/Malawi-CMAM-Guidelines-Dec2016.pdf

31. MISAU. Manual de tratamento e reabilitação nutricional volume I: 0 aos 14 anos [Internet]. 2018 [cited 2019 Nov 8]. Available from: https://www.fantaproject.org/sites/default/files/resources/PRN-I-Manual-Tratamento-Reabilitação-Nutricional-Vol-I-Set2018.pdf

32. Integrated management of acute malnutrition. National guidelines. 2018.

33. Training course on inpatient management of severe acute malnutrition. Children 6-59 months with SAM and medical complications. 2011.

34. Interim manual community-based management of severe acute malnutrition version 1.0 [Internet]. [cited 2019 Nov 8]. Available from: https://www.fantaproject.org/sites/default/files/resources/GOS CMAM Manual version 1.0 November2009.pdf

35. UNICEF. Prise en charge de la malnutrition aiguë sévère chez les enfants: vers des résultats à grande échelle guide des Programmes de l'unicef [Internet]. 2015 [cited 2019 Nov 8]. Available from: http://www.unicefinemergencies.com/ downloads/eresource/docs/2.3 Nutrition/SAM PRO 2015 French with links.pdf 
36. Jayatissa R, Bekele A, Kethiswaran A, De Silva AH. Community-based management of severe and moderate acute malnutrition during emergencies in Sri Lanka: challenges of implementation. Food Nutr Bull [Internet]. 2012 [cited 2019 Nov 8];33(4):251-60. Available from: http://journals.sagepub.com/doi/10.1177/156482651203300405

37. Kent Page, Unicef, DRC. Infant Feeding in Emergencies Module 2 Version 1.1 for health and nutrition workers in emergency situations [Internet]. 2007 [cited 2019 Nov 8]. Available from: http://www.ennonline.net/ife

38. Unicef. Plan National d'Action pour la Nutrition-III [Internet]. 2017 [cited 2019 Nov 8]. Available from: https://www. unicef.org/madagascar/sites/unicef.org.madagascar/files/2018-08/Madagascar-nutrition-PNAN3.pdf

39. FEX AC. Weighing scales for young infants: a survey of relief workers. 2006;

40. Ashworth A, Chopra M, McCoy D, Sanders D, Jackson D, Karaolis N, et al. WHO guidelines for management of severe malnutrition in rural South African hospitals: effect on case fatality and the influence of operational factors. Lancet [Internet]. 2004 [cited 2019 Nov 8];363(9415):1110-5. Available from: https://linkinghub.elsevier.com/retrieve/pii/ $\underline{\mathrm{s} 0140673604158947}$

41. Ashworth A. Treatment of severe malnutrition. J Pediatr Gastroenterol Nutr. 2001;32(5):516-518.

42. Bandsma RHJ, Spoelstra MN, Mari A, Mendel M, van Rheenen PF, Senga E, et al. Impaired glucose absorption in children with severe malnutrition. J Pediatr [Internet]. 2011 [cited 2019 Nov 8];158(2):282-287.e1. Available from: https://linkinghub.elsevier.com/retrieve/pii/S0022347610006268

43. Karaolis N, Jackson D, Ashworth A, Sanders D, Sogaula N, McCoy D, et al. WHO guidelines for severe malnutrition: are they feasible in rural African hospitals? Arch Dis Child [Internet]. 2007 [cited 2019 Nov 8];92(3):198-204. Available from: http://www.ncbi.nlm.nih.gov/pubmed/16670119

44. Thien H V., Kager PA, Sauerwein HP. Hypoglycemia in falciparum malaria: is fasting an unrecognized and insufficiently emphasized risk factor? Trends Parasitol [Internet]. 2006 [cited 2019 Nov 8];22(9):410-5. Available from: https://linkinghub. elsevier.com/retrieve/pii/S1471492206001759

45. Madrid L, Lanaspa M, Maculuve SA, Bassat Q. Malaria-associated hypoglycaemia in children. Expert Rev Anti Infect Ther [Internet]. 2015 [cited 2019 Nov 8];13(2):267-77. Available from: http://www.tandfonline.com/doi/full/10.1586/14787 210.2015.995632

46. Njomatchoua AC, Tankeu AT, Sobngwi E, Mbanya J-C. Glycemic effects of quinine infusion in healthy volunteers. BMC Res Notes [Internet]. 2017 [cited 2019 Nov 8];10(1):423. Available from: http://www.ncbi.nlm.nih.gov/pubmed/28836995

47. Cox CD, Anderson AC, Chittivelu S. Quinine overdose: hypoglycemia potentiated by age and alcohol. J Pharm Technol [Internet]. 2001 [cited 2019 Nov 8];17(6):270-2. Available from: http://journals.sagepub.com/ doi/10.1177/875512250101700605

48. MSF. Nutrition Guidelines. 2nd edition. 2006.

49. Maitland K, Berkley JA, Shebbe M, Peshu N, English M, Newton CRJC. Children with severe malnutrition: can those at highest risk of death be identified with the WHO protocol? Molyneux E, editor. PLoS Med [Internet]. 2006 [cited 2019 Nov 17];3(12):e500. Available from: https://dx.plos.org/10.1371/journal.pmed.0030500

50. Ashworth A, Khanum S, Jackson A, Schofield C. Guidelines for the inpatient treatment of severely malnourished children [Internet]. 2003 [cited 2019 Nov 17]. Available from: https://apps.who.int/iris/bitstream/handle/10665/42724/9241546093. pdf?sequence $=1$

51. Rerksuppaphol L, Rerksuppaphol S. Efficacy of zinc supplementation in the management of acute diarrhoea: a randomised controlled trial. Paediatr Int Child Health [Internet]. 2019 [cited 2019 Nov 17];1-6. Available from: http://www. ncbi.nlm.nih.gov/pubmed/31578136

52. Lazzerini M, Ronfani L. Oral zinc for treating diarrhoea in children. In: Lazzerini M, editor. Cochrane Database of Systematic Reviews [Internet]. Chichester, UK: John Wiley \& Sons, Ltd; 2012 [cited 2019 Nov 17]. p. CD005436. Available from: http://www.ncbi.nlm.nih.gov/pubmed/22696352

53. Somji SS, Dhingra P, Dhingra U, Dutta A, Devi P, Kumar J, et al. Effect of dose reduction of supplemental zinc for childhood diarrhoea: study protocol for a double-masked, randomised controlled trial in India and Tanzania. BMJ Paediatr Open [Internet]. 2019 [cited 2019 Nov 17];3(1):e000460. Available from: http://bmjpaedsopen.bmj.com/lookup/doi/10.1136/ bmipo-2019-000460

54. Petti CA, Polage CR, Quinn TC, Ronald AR, Sande MA. Laboratory medicine in Africa: a barrier to effective health care. Clin Infect Dis [Internet]. 2006 [cited 2019 Nov 17];42(3):377-82. Available from: https://academic.oup.com/cid/article-lookup/doi/10.1086/499363

55. Gutierrez-Mazariegos J, Theodosiou M, Campo-Paysaa F, Schubert M. Vitamin A: a multifunctional tool for development. Semin Cell Dev Biol [Internet]. 2011 [cited 2019 Nov 17];22(6):603-10. Available from: https://linkinghub.elsevier.com/ retrieve/pii/S1084952111000814 
56. Kanungo J. Retinoic acid signaling in P19 stem cell differentiation. Anticancer Agents Med Chem [Internet]. 2017 [cited 2019 Nov 17];17(9). Available from: http://www.eurekaselect.com/143305/article

57. Sommer A. Preventing blindness and saving lives: the centenary of vitamin A. JAMA Ophthalmol [Internet]. 2014 [cited 2019 Nov 17];132(1):115-7. Available from: http://archopht.jamanetwork.com/article.aspx?doi=10.1001/jamaophthal$\underline{\text { mol.2013.5309 }}$

58. Paganelli A, Gnazzo V, Acosta H, López SL, Carrasco AE. Glyphosate-based herbicides produce teratogenic effects on vertebrates by impairing retinoic acid signaling. Chem Res Toxicol [Internet]. 2010 [cited 2019 Nov 17];23(10):1586-95. Available from: http://www.ncbi.nIm.nih.gov/pubmed/20695457

59. Robinson JF, Verhoef A, Pennings JLA, Pronk TE, Piersma AH. A comparison of gene expression responses in rat whole embryo culture and in vivo: time-dependent retinoic acid-induced teratogenic response. Toxicol Sci [Internet]. 2012 [cited 2019 Nov 17];126(1):242-54. Available from: https://academic.oup.com/toxsci/article-lookup/doi/10.1093/toxsci/kfr342

60. de Medeiros PHQS, Pinto D V, de Almeida JZ, Rêgo JMC, Rodrigues FAP, Lima AÂM, et al. Modulation of intestinal immune and barrier functions by vitamin A: implications for current understanding of malnutrition and enteric infections in children. Nutrients [Internet]. 2018 [cited 2019 Nov 17];10(9):1128. Available from: http://www.mdpi.com/2072$6643 / 10 / 9 / 1128$

61. Yaikhomba T, Poswal L, Goyal S. Assessment of iron, folate and vitamin B12 status in severe acute malnutrition. Indian J Pediatr [Internet]. 2015 [cited 2019 Nov 17];82(6):511-4. Available from: http://link.springer.com/10.1007/s12098-014-1600-7

62. Thakur N, Chandra J, Pemde H, Singh V. Anemia in severe acute malnutrition. Nutrition [Internet]. 2014 [cited 2019 Nov 17];30(4):440-2. Available from: https://linkinghub.elsevier.com/retrieve/pii/S0899900713004437

63. Villalpando S, Cruz V de la, Shamah-Levy T, Rebollar R, Contreras-Manzano A. Nutritional status of iron, vitamin B12, folate, retinol and anemia in children 1 to 11 years old: results of the Ensanut 2012. Salud Publica Mex [Internet]. 2015 [cited 2019 Nov 17];57(5):372-84. Available from: http://www.saludpublica.mx/index.php/spm/article/view/7616

64. Metz J. A high prevalence of biochemical evidence of vitamin B12 or folate deficiency does not translate into a comparable prevalence of anemia. Food Nutr Bull [Internet]. 2008 [cited 2019 Nov 17];29(2 Suppl):S74-85. Available from: http:// journals.sagepub.com/doi/10.1177/15648265080292S111

65. Shah R, Javdekar B. Management of children with severe acute malnutrition: experience of nutrition rehabilitation centre at Baroda, Gujarat. Int J Contemp Pediatr [Internet]. 2014 [cited 2019 Nov 17];1(1):3. Available from: http://www. ijpediatrics.com

66. Islam MM, Huq S, Hossain MI, Ahmed AMS, Ashworth A, Mollah MAH, et al. Efficacy of F-100, diluted F-100, and infant formula as rehabilitation diet for infants aged $<6$ months with severe acute malnutrition: a randomized clinical trial. Eur J Nutr [Internet]. 2019 [cited 2019 Nov 17]; Available from: http://www.ncbi.nlm.nih.gov/pubmed/31367914

67. Lanyero B, Namusoke H, Nabukeera-Barungi N, Grenov B, Mupere E, Michaelsen KF, et al. Transition from F-75 to ready-touse therapeutic food in children with severe acute malnutrition, an observational study in Uganda. Nutr J [Internet]. 2017 [cited 2019 Nov 17];16(1):52. Available from: http://nutritionj.biomedcentral.com/articles/10.1186/s12937-017-0276-z

68. Rytter MJH, Babirekere-Iriso E, Namusoke H, Christensen VB, Michaelsen KF, Ritz C, et al. Risk factors for death in children during inpatient treatment of severe acute malnutrition: a prospective cohort study. Am J Clin Nutr [Internet]. 2017 [cited 2019 Nov 17];105(2):494-502. Available from: https://academic.oup.com/ajcn/article/105/2/494-502/4633943

69. Schoonees A, Lombard MJ, Musekiwa A, Nel E, Volmink J. Ready-to-use therapeutic food (RUTF) for home-based nutritional rehabilitation of severe acute malnutrition in children from six months to five years of age. Cochrane database Syst Rev [Internet]. 2019 [cited 2019 Nov 17];5(5):CD009000. Available from: http://doi.wiley.com/10.1002/14651858. CD009000.pub3 